\title{
TELAAH TERHADAP HUBUNGAN HUKUM DAN KEKUASAAN
}

\author{
Andi Safriani \\ Universitas Islam Negeri (UIN) Alauddin Makassar \\ Email: aydinriany13@gmail.com
}

\begin{abstract}
In principle law and power have interrelated relationships with each other. The law Exist because it is made legitimate ruler, on the contrary the actions of the ruler are governed by the law it makes. Between law and power must be balanced, to exercise power there must be law as a limitation for the exercise of the power, whereas in the execution of the law there must be power for law enforcement or its apparatus so that the law can be obeyet by society.
\end{abstract}

Key Word : Relationship, Law and Power

\begin{abstract}
Abstrak
Pada prinsipnya, Hukum dan Kekuasaan memiliki hubungan yang saling mempengaruhi satu sama lain, hukum ada karena dibuat penguasa yang sah, sebaliknya perbuatan penguasa diatur oleh hukum yang dibuatnya. Antara hukum dan kekuasaan haruslah seimbang, untuk menjalankan kekuasaan haruslah ada hukum sebagai rambu atau batasan bagi pelaksanaan kekuasaan tersebut, sedangkan dalam pelaksanaan hukum tersebut haruslah ada kekuasaan bagi penegak hukum (aparat) nya agar hukum tersebut dapat ditaati oleh masyarakat.
\end{abstract}

Kata Kunci : Hubungan, Hukum dan Kekuasaan 


\section{PENDAHULUAN}

S uatu negara pasti membutuhkan peraturan atau hukum untuk mengatur atau mengelola masyarakatnya. Apabila hukum itu ingin ditegakkan, maka dibutuhkan suatu lembaga yang bisa menjalankan dan mengelola peraturan itu sendiri. Oleh karena itu, peran dari penguasa sangat dibutuhkan dalam hal ini. Hukum baru dapat dijalankan apabila ada penguasa yang mengaturnya.

Dalam kehidupan masyarakat, kekuasaan mempunyai arti penting bagi hukum karena kekuasaan bukan hanya merupakan instrumen pembentukan hukum (law making), tapi juga instrumen penegakan hukum (law enforcement).

Pembentukan hukum, khususnya undang-undang, dilakukan melalui mekanisme kekuasaan politik dalam lembaga legislatif di mana kepentingankepentingan kelompok masyarakat yang saling bertentangan diupayakan untuk dikompromikan guna menghasilkan satu rumusan kaidah-kaidah hukum yang dapat diterima semua pihak. Penegakan hukum merupakan upaya untuk mendorong masyarakat agar mentaati aturan-aturan hukum yang berlaku (upaya preventif) dan penjatuhan sanksi hukum terhadap kasuskasus pelanggaran hukum yang terjadi dalam masyarakat (upaya represif).

Pentaatan dari ketentuan-ketentuan hukum dapat dipaksakan dengan cara teratur dalam arti tunduk pada aturan-aturan tertentu baik mengenai bentuk,cara maupun alat pelaksanaannya. Dalam suatu negara pemaksaan berlakunya ketentuan-ketentuan ini berada ditangan negara beserta alat-alat perlengkapannya.

Hukum juga mempunyai arti penting bagi kekuasaan karena hukum dapat berperan sebagai sarana legalisasi bagi kekuasaan formal lembagalembaga negara, unit-unit pemerintahan, pejabat negara dan pemerintahan. Legalisasi kekuasaan itu dilakukan melalui penetapan landasan hukum bagi kekuasaan melalui aturanaturan hukum. Di samping itu, hukum dapat pula berperan mengontrol kekuasaan sehingga pelaksanaannya dapat dipertanggungjawabkan secara legal dan etis.

Karakteristik hubungan hukum dan kekuasaan, khususnya dalam hal legalisasi kekuasaan dan penegakan hukum, dijelaskan oleh Mochtar Kusumaatmadja dalam satu ungkapkan "hukum tanpa kekuasaan adalah anganangan, dan kekuasaan tanpa hukum adalah kezaliman". Ungkapan tersebut, pada satu sisi, mengandung arti bahwa kaidah-kaidah hukum tidak akan ada manfaatnya jika tidak ditegakkan, dan hukum itu hanya dapat ditegakkan dengan kekuasaan. Pada sisi lain, ungkapan itu bermakna bahwa kekuasaan tanpa landasan hukum adalah kesewenang wenangan.

Dalam kenyataannya banyak terjadi ketidakadilan sebagai akibat disalahgunakannya kekuasaan untuk kepentingan diri sendiri maupun kelompok 
penguasa, dimana perilaku buruk itu tidak hanya terjadi secara acak akan tetapi sudah melembaga secara struktural.

Sering menjadi permasalahan adalah tolok ukur legalitas kekuasaan. Apakah setiap kekuasaan yang berdasarkan aturan hukum dapat dikualifikasikan sebagai kekuasaan sah atau legal, Apakah kekuasaan sewenang-wenang yang memiliki landasan hukum harus diterima dan ditaati, Apakah kekuasaan yang sewenang-wenang dapat melahirkan hukum yang adil, Apakah efektivitas penegakan hukum tergantung pada legalitas kekuasaan, dan apakah kekuasaan legal yang sewenang-wenang dapat menegakkan hukum guna mencapai keadilan?

Meskipun hukum mempunyai hubungan yang sangat erat dengan kekuasaan, tapi studi kekuasaan dalam perspektif hukum masih terbatas sehingga konsep-konsep kekuasaan di dalam ilmu hukum tidak begitu berkembang. Kecenderungan studi hukum lebih terfokus kepada 2 aspek, pertama yaitu hukum dipandang sebagai kaidah yang menjadi pedoman tingkah laku yang bersifat memaksa dan memberikan sanksi kepada orang yang melanggarnya,dan yang kedua hukum dipandang sebagai realitas sosial yang terjadi di masyarakat yang dipraktikkan melalui lembaga peradilan (the living law), adanya pelanggaranpelanggaran hukum (perilaku pelanggar hukum), dan ketaatan terhadap hukum.

\section{PEMBAHASAN}

\section{A. Kekuasaan}

Kekuasaan merupakan konsep hubungan sosial yang terdapat dalam kehidupan masyarakat, negara, dan umat manusia. Konsep hubungan sosial itu meliputi hubungan personal di antara dua insan yang berinteraksi, hubungan institusional yang bersifat hierarkis, dan hubungan subjek dengan objek yang dikuasainya. Karena kekuasaan memiliki banyak dimensi, maka tidak ada kesepahaman di antara para ahli politik, sosiologi, hukum dan kenegaraan mengenai pengertian kekuasaan.

Max Weber, dalam bukunya Wirtschaft und Gesellschaft (1992) mengemukakan bahwa "kekuasaan adalah kemampuan untuk, dalam suatu hubungan sosial, melaksanakan kemauan sendiri sekalipun mengalami perlawanan, dan apa pun dasar kemampuan ini." Perumusan kekuasaan yang dikemukakan Weber dijadikan dasar perumusan pengertian kekuasaan oleh beberapa pemikir lain Misalnya, Strausz-Hupe mendefinisikan kekuasaan sebagai "kemampuan untuk memaksakan kemauan pada orang lain" Demikian pula pengertian yang dikemukakan oleh C. Wright Mills, "kekuasaan itu adalah dominasi, yaitu kemampuan untuk melaksanakan kemauan kendatipun orang lain menentang, artinya kekuasaan mempunyai sifat memaksa" 
Menurut Talcot Parsons, kekuasaan adalah kemampuan umum untuk menjamin pelaksanaan dari kewajiban-kewajiban yang mengikat oleh unit-unit organisasi kolektif dalam suatu sistem yang merupakan kewajiban-kewajiban yang diakui dengan acuan kepada pencapaian tujuan-tujuan kolektif mereka dan bila ada pengingkaran terhadap kewajiban-kewajiban dapat dikenai oleh sanksi negatif tertentu, siapapun yang menegakkannya. Pengertian ini menitikberatkan kepada kekuasaan publik untuk menegakkan aturan-aturan masyarakat yang bersifat memaksa demi untuk memberikan perlindungan kepada masyarakat.

Di samping pengertian kekuasaan sebagai kemampuan untuk memaksakan kehendak atau kemauan kepada pihak lain, beberapa pakar mengartikan kekuasaan sebagai kemampuan untuk membatasi tingkah laku pihak lain. Harold D.Laswell,5 dan Abraham Kaplan mengatakan bahwa "kekuasaan adalah suatu hubungan di mana seseorang atau kelompok orang dapat menentukan tindakan seseorang atau kelompok lain agar sesuai tujuan dari pihak pertama.

Kekuasaan dalam kaitannya dengan masalah kenegaraan, dapat dibedakan ke dalam dua kelompok, yaitu kekuasaan negara dan kekuasaan masyarakat. Kekuasaan negara berkaitan dengan otoritas negara untuk mengatur kehidupan masyarakat secara tertib dan damai.

Kekuasaan masyarakat adalah kekuatan/kemampuan masyarakat untuk mengelola dan mengorganisasikan kepentingan individu-individu dan kelompokkelompok masyarakat yang menjadi anggotanya sehingga interaksi sosial dapat berjalan secara lancar. Ketidakseimbangan diantara keduanya akan mendorong terjadinya kekuasaan hegemonik di mana negara sangat kuat dan masyarakat sangat lemah, sehingga tercipta pola hubungan dominatif dan eksploitatif. Hal ini mengakibatkan negara bukan hanya campur tangan dalam urusan-urusan kenegaraan dan kemasyarakatan, tetapi juga intervensi atas seluruh tindakan masyarakat yang sebenarnya bukan dalam lingkup wewenangnya.

\section{B. Esensi Hukum}

Mengenai esensi hukum dapat dikemukakan bahwa ada perbedaan pandangan di antara para ahli hukum tentang hukum. Perbedaan pandangan itu dapat dilihat dari pengertian hukum yang mereka kemukakan yang berbeda antara yang satu dengan yang lainnya. Meskipun ada perbedaan pandangan, namun pengertian itu dapat diklasifikasikan dalam empat kelompok.

Pertama, hukum diartikan sebagai nilai-nilai. Misalnya, Victor Hugo yang mengartikan hukum sebagai kebenaran dan keadilan. Sejalan dengan pengertian tersebut, Grotius mengemukakan bahwa hukum adalah suatu aturan moral tindakan yang wajib yang merupakan sesuatu yang benar. Pembahasan hukum 
dalam konteks nilai-nilai berarti memahami hukum secara filosofis karena nilainilai merupakan abstraksi tertinggi dari kaidah-kaidah hukum.

Kedua, hukum diartikan sebagai asas-asas fundamental dalam kehidupan masyarakat Definisi hukum dalam perspektif ini terlihat dalam pandangan Salmond9 yang mengatakan "hukum merupakan kumpulan asas-asas yang diakui dan diterapkan oleh negara di dalam peradilan".

Ketiga, hukum diartikan sebagai kaidah atau aturan tingkah laku dalam kehidupan masyarakat. Vinogradoff10 mengartikan hukum sebagai seperangkat aturan yang diadakan dan dilaksanakan oleh suatu masyarakat dengan menghormati kebijakan dan pelaksanaan kekuasaan atas setiap manusia dan barang. Pengertian yang sama dikemukakan oleh Kantorowich, yang berpendapat bahwa hukum adalah suatu kumpulan aturan sosial yang mengatur perilaku lahir dan berdasarkan pertimbangan.

Keempat, hukum diartikan sebagai kenyataan (das sein) dalam kehidupan masyarakat. Hukum sebagai kenyataan sosial mewujudkan diri dalam bentuk hukum yang hidup (the living law) dalam masyarakat atau dalam bentuk perilaku hukum masyarakat. Perilaku hukum terdiri dari perilaku melanggar hukum (pelanggaran hukum) dan perilaku menaati aturan-aturan hukum.

Perbedaan pandangan di antara ahli hukum bukan hanya mengenai pengertian hukum, tapi juga mengenai hakekat hukum. Perbedaan pandangan mengenai hakekat hukum ini tergambar dari munculnya berbagai mazhab dalam pemikiran hukum. Pertanyaan pokok tentang hakekat hukum berkaitan dengan hukum yang benar, apakah hukum yang benar? Jawaban atas pertanyaan prinsipil tersebut beraneka ragam dan saling kontradiktif.

Dalam paham hukum agama yang teistik, hakekat hukum adalah perintah Allah. Hukum yang benar adalah hukum yang difirmankan dan diperintahkan oleh Tuhan. Menurut doktrin Islam, hukum yang benar adalah hukum Allah yang dirumuskan dalam Qur'an, dan hukum yang disabdakan Rasul dalam hadis. Sedangkan bagi paham sekuler, hakekat hukum tidak ada hubungannya dengan urusan keagamaan dan ketuhanan, tapi merupakan urusan peradilan, kemasyarakatan, dan kenegaraan.

Dalam konteks ini hakekat hukum bisa ditinjau dari empat perspektif, yaitu perspektif otoritas (wewenang), perspektif substantif, perspektif sosiologis, dan perspektif realis. Perspektif otoritas merupakan pandangan paham positivisme yang menempatkan keabsahan hukum pada otoritas pembentukan dan penegakan hukum. 


\section{C.Hubungan Hukum dan Kekuasaan}

Hukum dan kekuasaan merupakan dua hal yang berbeda namun saling mempengaruhi satu sama lain. Hukum merupakan suatu system peraturan yang mengatur kehidupan manusia dan apabila dilanggar, maka akan diberikan sanksi bagi yang melanggarnya. Sedangkan kekuasaan adalah kemampuan seseorang atau suatu kelompok untuk mempengaruhi perilaku seseorang atau kelompok lain, agar pihak tersebut bertindak sesuai dengan apa yang mereka inginkan.

Masyarakat menciptakan kaidah hukum yang kepatuhannya pada tingkat terakhir tidak sepenuhnya diserahkan pada kemauan bebas warga masyarakat perorangan, melainkan diterapkan dan ditegakkan oleh otoritas publik yang kewenangan, dan kehadirannya diterima oleh masyarakat.

Untuk mengatahui apakah hukum itu berfungsi didalam masyarakat maka yang harus diketahui adalah apakah hukum itu benar-benar berlaku dalam masyarakat. Mengenai berlakunya hukum dalam masyarakat, terdapat beberapa anggapan, yaitu:

1. Kaidah hukum berlaku secara yuridis, apabila penentuannya didasarkan pada kaidah yang lebih tinggi tingkatannya (Hans Kelsen) atau bila berbentuk menurut cara yang telah ditetapkan, atau apabila menunjukkan hubungan antara suatu kondisi dan akibatnya (J.H.A.Logemann).

2. Hukum itu berlaku secara sosiologis, apabila kaidah tersebut efektif. Artinya kaidah tersebut dapat dipaksakan berlakunya oleh penguasa walaupun tidak diterima oleh warga masyarakat atau kaidah tadi berlaku karena diterima dan diakui oleh masyarakat.

3. Kaidah hukum tersebut berlaku secara filosofis, artinya sesuai dengan citacita hukum sebagai nilai positif yang tertinggi.

Pelaksanaan hukum dalam masyarakat memerlukan kekuasaan, sebab tanpa kekuasaan hukum hanya bersifat anjuran. Akan tetapi sebaliknya kekuasaan pun memerlukan hukum untuk menentukan batas-batasnya.

Kekuasaan memiliki sifat yang khas, yaitu bahwa ia cenderung untuk merangsang yang memilikinya untuk lebih berkuasa lagi. Oleh sebab itu, maka kekuasaan dapat dimulai baik atau buruknya tergantung dari bagaimana si pemegang kekuasaan menggunakannya, Artinya, baik buruknya kekuasaan senantiasa harus diukur dengan kegunaannya untuk mencapai suatu tujuan yang sudah ditentukan atau disadari oleh masyarakat lebih dahulu. Hal ini merupakan suatu unsur yang mutlak bagi kehidupan masyarakat yang tertib atau bahkan bagi setiap bentuk organisasi yang teratur.

Pemegang kekuasaan memiliki peranan yang sangat penting, dimana untuk dapat terwujudnya keadilan yang dicita-citakan antara lain akan bergantung 
kepada bagaimana pemegang kekuasaan menggunakan kekuasaannya. Oleh sebab itu disamping dibutuhkan hukum dan kesadaran hukum masyarakat sebagai pembatas bagi pemegang kekuasaan, hal lain yang tidak kalah pentingnya adalah kejujuran dan moral yang tinggi bagi kepentingan masyarakat. Sebab sebaik apapun hukum diadakan untuk membatasi perilaku penguasa, namun jika mental dan moral penguasa tidak baik, pada akhirnya hukum justru akan diinjak-injak.

Untuk mengetahui keeratan hubungan antara hukum dan kekuasaan, dapat dilihat melalui dua cara, yaitu:

1. Menelaah dari konsep sanksi.

Adanya perilaku yang tidak mematuhi aturan-aturan hukum menyebabkan diperlukan sanksi untuk penegakan aturan-aturan hukum tadi, karena sanksi merupakan bentuk kekerasan, maka penggunaanya memerlukan legitimasi yuridis (pembenaran hukum) agar menjadikannya sebagai kekerasan yang sah.

2. Menelaah dari konsep penegakan konstitusi.

Pembinaan sistem aturan-aturan hukum dalam suatu negara yang teratur adalah diatur oleh hukum itu sendiri, yang biasanya tercantum dalam konsitusi negara yang bersangkutan. Penegakan konstitusi itu, termasuk penegakan prosedur yang benar dalam pembinaan hukum tadi mengasumsikan digunakannya kekuatan. Artinya bahwa hukum sendiri harus mendapatkan perlindungan untuk kepentingan penegakannya yaitu kekuasaan.

Di samping hukum sama dengan kekuasaan, pola hubungan hukum dan kekuasaan yang lain adalah bahwa hukum tidak sama dengan kekuasaan. Artinya, hukum dan kekuasaan merupakan dua hal yang terpisah, tapi ada hubungan yang erat di antara keduanya. Hubungan itu dapat berupa hubungan dominatif dan hubungan resiprokal (timbal balik). Ada tiga bentuk manifestasi hubungan hukum dan kekuasaan dalam konteks ini, yaitu:

a. Pertama, hukum tunduk kepada kekuasaan. Maksudnya, hukum bukan hanya menjadi subordinasi kekuasaan, tapi juga sering menjadi alat kekuasaan, dengan kata lain, kekuasaan memiliki supremasi terhadap hukum. Oleh karena itu, definisi hukum yang dikemukakan oleh para ahli menempatkan hukum berada di bawah kontrol kekuasaan.

b. Kedua, kekuasaan tunduk kepada hukum. Artinya, kekuasaan berada di bawah hukum dan hukum yang menentukan eksistensi kekuasaan. Dalam pemikiran hukum, tunduknya kekuasaan kepada 
hukum merupakan konsep dasar dalam penyelenggaraan ketatanegaraan. Konsep itu dirumuskan dalam terminologi supremasi hukum (supreme of law). Supremasi hukum berarti bahwa hukum merupakan kaidah tertinggi untuk mengatur kehidupan bermasyarakat, berbangsa dan bernegara. Hukum sebagai kaidah tertinggi muncul dalam konsep norma dasar negara (staats fundamental norm) atau grund norm menurut pemikiran Hans Kelsen. Di samping itu, supremasi hukum juga berarti bahwa penggunaan kekuasaan untuk menjalankan kehidupan ketatanegaraan dan roda pemerintahan harus berdasarkan kepada aturan hukum. Tanpa landasan hukum, kekuasaan tidak memiliki legalitas.

c. Ketiga, ada hubungan timbal balik (simbiotik) antara hukum dan kekuasaan. Dalam hal ini hubungan hukum dan kekuasaan tidak bersifat dominatif di mana yang satu dominan atau menjadi faktor determinan terhadap yang lain, tapi hubungan pengaruh mempengaruhi yang bersifat fungsional, artinya hubungan itu dilihat dari sudut fungsi-fungsi tertentu dan dapat dijalankan di antara keduanya.

Antara hukum dan kekuasaan terjadi hubungan yang saling mempengaruhi satu sama lain. Apabila hukum yang berlaku tanpa adanya kekuasaan didalamnya, maka hukum tersebut menjadi tidak mempan dalam menjalankan fungsinya mengatur masyarakat karena masyarakat tidak akan patuh terhadap hukum tersebut dikarenakan tidak ada pihak yang bberwenang untuk menegakkan hukum tersebut sehingga dapat menyebabkan kacaunya kondisi yang ada dalam masyarakat.

Eksistensi hukum tanpa ada kekuasaan yang melatarbelakanginya membuat hukum menjadi mandul, sedangkan kekuasaan yang diatur oleh hukum adalah untuk kepentingan masyarakat agar masyarakat yang merupakan objek dari kekuasaan tidak menjadi korban dari kekuasaan.

\section{PENUTUP}

Pada prinsipnya, Hukum dan Kekuasaan memiliki hubungan yang saling mempengaruhi satu sama lain, hukum ada karena dibuat penguasa yang sah, sebaliknya perbuatan penguasa diatur oleh hukum yang dibuatnya. Antara hukum dan kekuasaan haruslah seimbang, untuk menjalankan kekuasaan haruslah ada hukum sebagai rambu atau batasan bagi pelaksanaan kekuasaan tersebut, sedangkan dalam pelaksanaan hukum tersebut haruslah ada kekuasaan bagi penegak hukum (aparat) nya agar hukum tersebut dapat ditaati oleh masyarakat. 


\section{DAFTAR PUSTAKA}

Achmad Ali, Menguak Tabir Hukum, Chandra Pratama. Jakarta, 1996

B. Arief Sidharta, Refleksi Terhadap Paradigma Ilmu Hukum di Indonesia, Pps Unpad, Bandung, 1999.

J.J.H Bruggink, alih bahasa Arief Sidharta, Refleksi tentang Hukum, Citra Aditya Bandung, 1996

Jujun Suriasumantri, Filsafat Ilmu Sebuah Pengantar Populer, Pustaka Sinar Harapan, Jakarta, 2009.

Lili Rasyidi, Dasar-dasar Filsafat Hukum, Citra Aditya Bandung, 1996

Miriam Budiardjo, Aneka Pemikiran Tentang Kuasa Dan Wibawa, Sinar Harapan, Jakarta, 1991.

Soekarno Aburaerah,Dkk, Filsafat Hukum, Refleksi Makassar, 2010

http://samardi wordpress.com/2011/hubungan hukum dan kekuasaan.

www.geoogle.com (Nanik Trihastuti, Hubungan hukum dan kekuasaan dalam Filsafat Hukum). 